
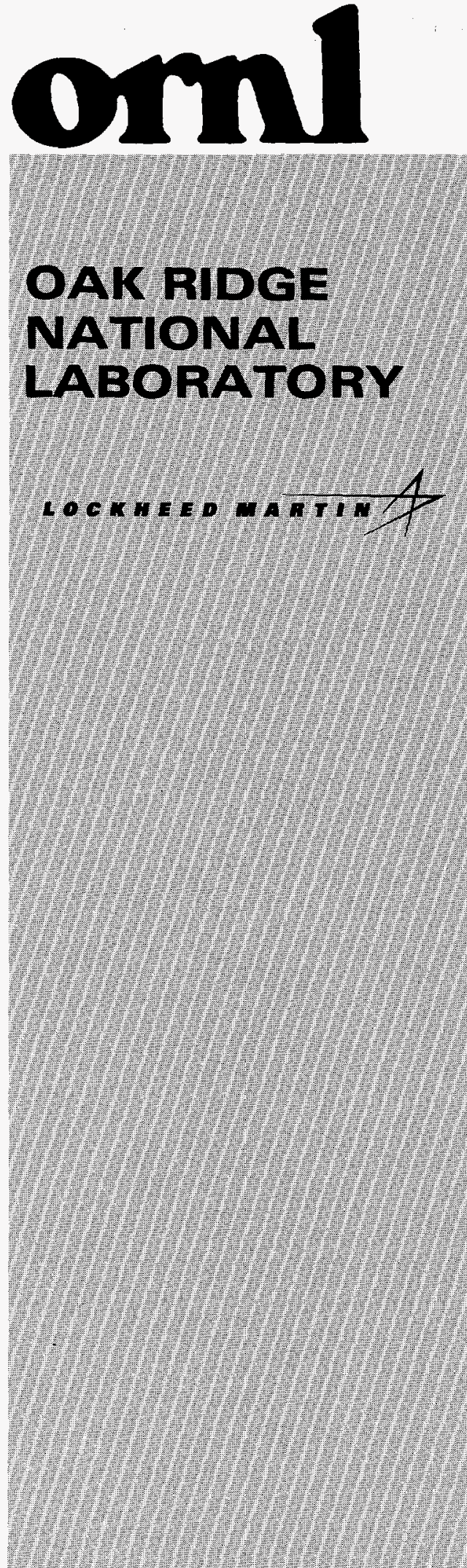

WAMAGED ANO OPERATEO BY LOCKHEED WARTNN ENERGY RESEARCH CORPORATION FOP THE UITTEO STATES DEPARTUENT OF ENERGY

\section{OSTI \\ Quarterly Progress Report for the Chemical Development Section of the Chemical Technology Division: April-June 1996}

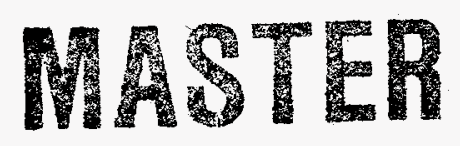

DISTRIBUTION OF THIS DOCUMENT IS UNUMTED 
This report has been reproduced directly from the best available copy.

Available to DOE and DOE contractors from the Office of Scientific and Technical Information, P. O. Box 62. Oak Ridge, TN 37831; prices available from (423) 576-8401. FTS 626-8401.

Available to the public from the National Technical Information Service, U.S. Department of Commerce, 5285 Port Royal Road, Springfield, VA 22161.

This report was prepared as an account of work sponsored by an agency of the United States Government. Neither the United States Government nor any agency thereof, nor any of their employees, makes any warranty, express or implied, or assumes any legal liability or responsibility for the accuracy. completeness, or usefulness of any information, apparatus, product, or process disclosed, or represents that its use would not infringe privately owned rights. Reference herein to any specific commercial product. process, or service by trade name. trademark, manufacturer, or otherwise, does not necessarily constitute or imply its endorsement, recommendation, or favoring by the United States Government or any agency thereof. The views and opinions of authors expressed herein do not necessarily state or reflect those of the United States Government of any agency thereof. 
Chemical Technology Division

\title{
QUARTERLY PROGRESS REPORT FOR THE CHEMICAL DEVELOPMENT SECTION OF THE CHEMICAL TECHNOLOGY DIVISION: \\ APRIL-JUNE 1996
}

\author{
R. T. Jubin
}

Date Published-November 1996

Prepared by the

OAK RIDGE NATIONAL LABORATORY

Oak Ridge, Tennessee 37831-6285

managed by

LOCKHEED MARTIN ENERGY RESEARCH CORP.

for the

U.S. DEPARTMENT OF ENERGY

under contract DE-AC05-96OR22464 


\section{DISCLAMMER}

Portions of this document may be illegible in electronic image products. Images are produced from the best available original document. 


\section{CONTENTS}

EXECUTIVE SUMMARY $\ldots \ldots \ldots \ldots \ldots \ldots \ldots \ldots \ldots \ldots \ldots \ldots \ldots \ldots \ldots \ldots$

1. CHEMICAL PROCESSES FOR WASTE MANAGEMENT $\ldots \ldots \ldots \ldots \ldots \ldots \ldots \ldots 1$

1.1 COMPREHENSIVE SUPERNATE TREATMENT $\ldots \ldots \ldots \ldots \ldots \ldots \ldots \ldots$

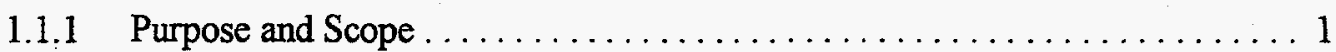

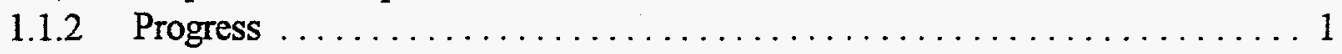

1.2 PARTITIONING OF SLUDGE COMPONENTS BY CAUSTIC LEACHING $\ldots \ldots 3$

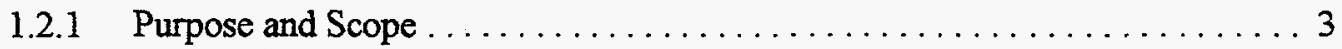

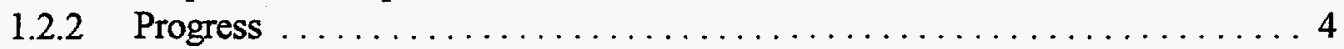

1.3 STUDIES ON TREATMENT OF DISSOLVED MVST SLUDGE USING

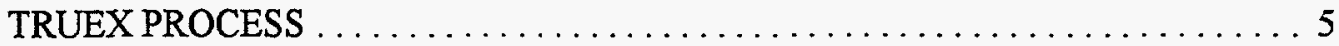

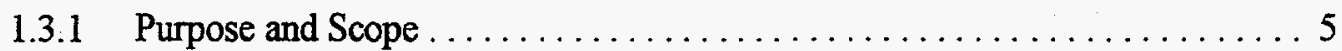

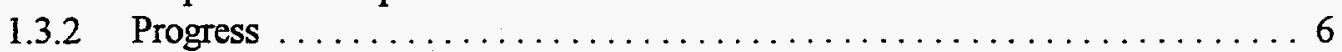

$1.4 \mathrm{ACT} * \mathrm{DE}^{*} \mathrm{CON}{ }^{S M}$ PROCESS TEST PROGRAM $\ldots \ldots \ldots \ldots \ldots \ldots \ldots \ldots$

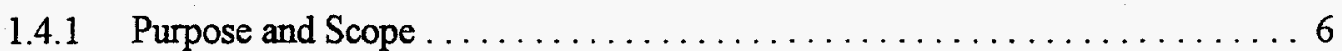

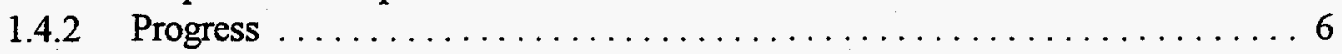

1.5 HOT DEMONSTRATION OF PROPOSED COMMERCIAL NUCLIDE

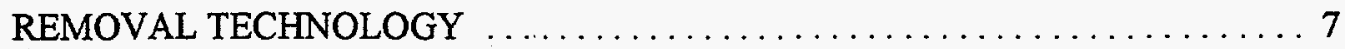

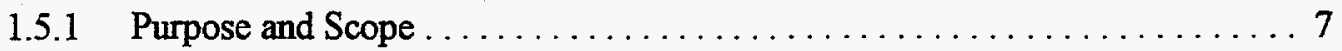

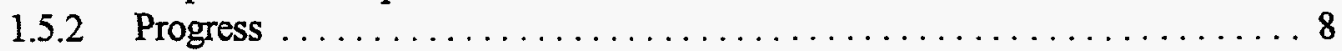

1.5.2.1 Superlig® $644 \mathrm{C}$ at $1 \mathrm{~N}$ Hydroxide and $3.5 \mathrm{CV} / \mathrm{h} \ldots \ldots \ldots \ldots$

1.5.2.2 RF Resin at $1 N$ Hydroxide and 3.5 CV/h . . . . . . . . 11

1.5.2.3 Batch Tests of the UPO IONSIV IE-911 CST . . . . . . . . . . 12

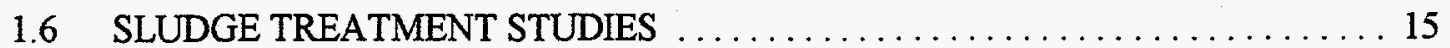

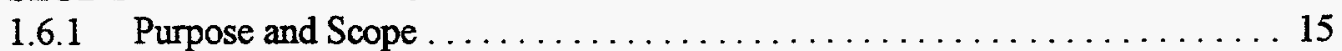

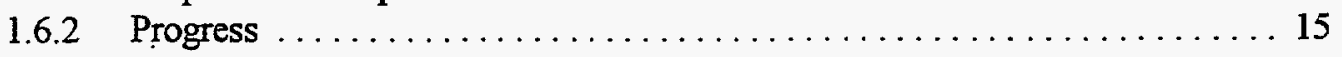

1.7 DEVELOPMENT AND TESTING OF INORGANIC SORBENTS $\ldots \ldots \ldots \ldots \ldots$

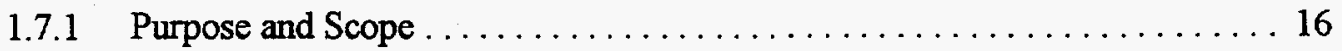

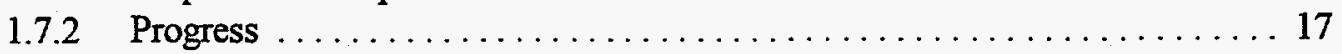

2. REACTOR FUEL CHEMISTRY-TECHNICAL ASSISTANCE IN REVIEW

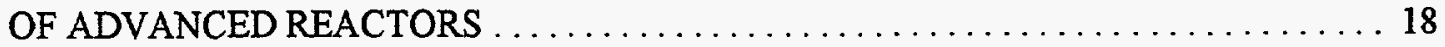

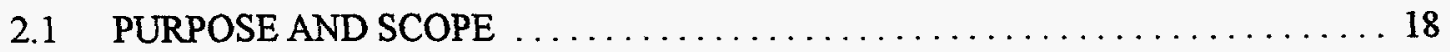

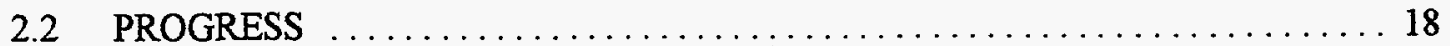

3. THERMODYNAMICS-THERMODYNAMICS AND KINETICS OF ENERGY-

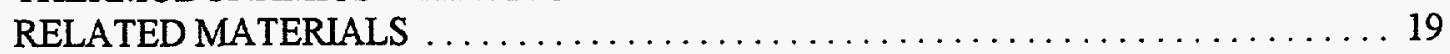

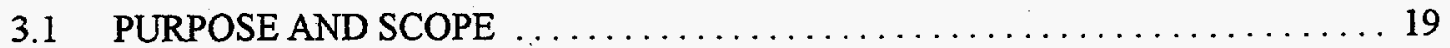

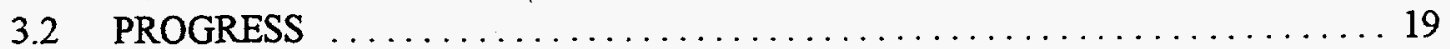


4. PROCESSES FOR WASTE MANAGEMENT $\ldots \ldots \ldots \ldots \ldots \ldots \ldots \ldots \ldots \ldots \ldots \ldots \ldots \ldots$

4.1 ION-EXCHANGE PROCESS FOR HEAVY METALS REMOVAL $\ldots \ldots \ldots \ldots 21$

4.1 .1 Purpose and Scope . . . . . . . . . . . . . . . . . . . . . . 21

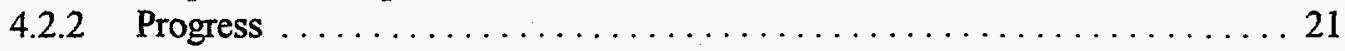

4.2 HOT CELL CROSS-FLOW FILTRATION STUDIES OF GUNITE

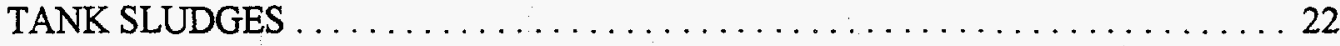

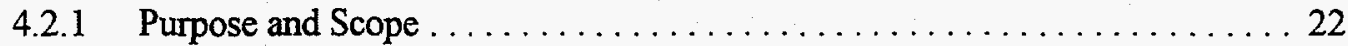

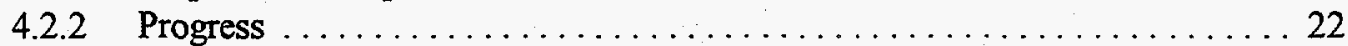

4.3 CHEMICAL CONVERSION OF NITRATE DIRECTLY TO NITROGEN

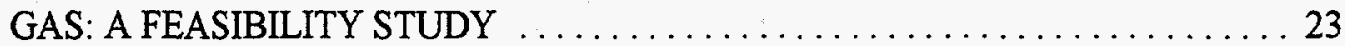

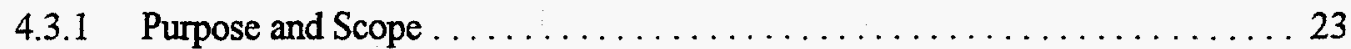

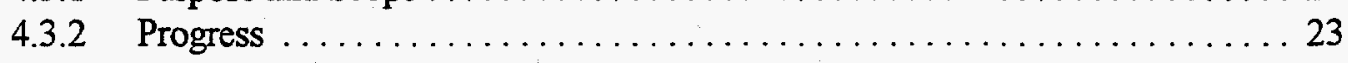




\section{EXECUTIVE SUMMARY}

This report summarizes the major activities conducted in the Chemical Development Section of the Chemical Technology Division at Oak Ridge National Laboratory (ORNL) during the period April-June 1996. The report describes 12 tasks conducted in 4 major areas of research and development within the section.

The first major research area-Chemical Processes for Waste Management-includes the following tasks: Comprehensive Supernate Treatment, Partitioning of Sludge Components by Caustic Leaching, Studies on Treatment of Dissolved MVST Sludge Using TRUEX Process, ACT ${ }^{*} \mathrm{DE}^{*} \mathrm{CON}^{\mathrm{SM}}$ Test Program, Hot Demonstration of Proposed Commercial Nuclide Removal Technology, Sludge Treatment Studies, and Development and Testing of Inorganic Sorbents.

As part of the Comprehensive Supernate Treatment task, a small-column test was conducted using Reillex HPQ anion-exchange resin to measure the removal of pertechnetate from ORNL Melton Valley Storage Tank (MVST) W-27 supernatant. The fractions from the small-column test were analyzed by inductively coupled plasma-mass spectroscopy (ICP-MS) to determine technetium content. The 50\% technetium breakthrough occurred at about 45 bed volumes. The technetium was eluted in about 7 bed volumes of eluent using a solution containing $0.017 \mathrm{M}$ stannous chloride, $0.1 \mathrm{M}$ ethylenediamine, and $0.075 \mathrm{M}$ sodium hydroxide.

A second small-column test using Eichrom ABEC-5000-XL anion-exchange resin to remove pertechnetate from ORNL MVST W-27 supernatant was also completed. Samples from this test are being analyzed for technetium using ICP-MS.

Several tests to measure the caustic dissolution behavior of Hanford tank sludges were completed as part of the Partitioning of Sludge Components by Caustic Leaching task. Two samples of Hanford tank S-104 sludge were leached with $3.9 \mathrm{MNaOH}$ at $70^{\circ} \mathrm{C}$ for 4 and $24 \mathrm{~h}$ to determine the effect of time on dissolution behavior. Two other samples were leached with $3.9 \mathrm{M} \mathrm{NaOH}$ at $70^{\circ} \mathrm{C}$ for $21 \mathrm{~h}$ using different leachant-to-sludge ratios to determine if the dissolution behavior is governed by limited solubility of specific components. Additional caustic leach tests were completed on sludge samples from Hanford tanks S-104 and SX-113 leached with $6 \mathrm{MNaOH}$ at $70^{\circ} \mathrm{C}$ for $21 \mathrm{~h}$.

Preliminary results from the S-104 sludge indicate a kinetic effect in the caustic leaching. Neither liquid-to-solid ratios greater than 5 or caustic concentrations that had been increased from $4 M$ to $6 M$ had a significant effect. Under identical conditions, the fraction of aluminum leached from SX-113 sludge was twice that leached from S-104 sludge.

Efforts in the Studies on Treatment of Dissolved MVST Sludge Using TRUEX Process task continued to focus on the preparation of an ORNL/TM report on the transuranium extraction (TRUEX) 
tests performed with dissolved MVST sludge. The report was largely completed by the end of the quarter.

The major activity of the $\mathrm{ACT}^{*} \mathrm{DE}^{*} \mathrm{CON}^{\mathrm{SM}}$ Test Program task involved completion (and publication in May) of ORNL/TM-13201, Evaluation of the $A C T^{*} D E^{*} C O N^{S M}$ Process for Treating Gunite Tank Sludge.

The Hot Demonstration of Proposed Commercial Nuclide Removal Technology task continued to address the continuous removal and concentration of radioactive components from supernatants at the various Department of Energy sites. The primary objective is to test candidate absorbers and ion exchangers under continuous-flow conditions using actual supernatant from the MVSTs. An experimental system contained in a hot-cell facility is used to test the materials in columns or modules using the same batch of supernatant so that they can all be compared on the same basis. During the last quarter, SuperLig $644 \mathrm{C}$ and resorcinol/formaldehyde (RF) resins were tested. The $R F$ resin was tested at a feed concentration of $5.5 \mathrm{M}$ sodium, $1 \mathrm{M}$ hydroxide, and $1 \times 10^{-5} \mathrm{M}$ cesium. The SuperLig resin was tested for one loading at the above concentrations and three loadings at a cesium concentration of $7 \times 10^{-5}$ $M$. The same resin was loaded and eluted four times. Batch tests were also conducted to help decide the tank and adjustment requirements for the Cesium Removal Demonstration Project using the IONSIV 911 CST.

Within the Sludge Treatment Studies task, test results from two Enhanced Sludge Washing sequences run on sludge from Hanford underground storage tank T-104 provided direct evidence that phosphate reprecipitated into the sludge residue-leachate mixture when the temperature was decreased from $75^{\circ} \mathrm{C}$ to ambient. This resulted in the formation of a gelatinous material that sticks to the walls of the container. The results show that phosphate solids will form if the correct leaching temperature is not maintained throughout the process.

During the quarter, several batches of hydrous titanium oxide microspheres were prepared as part of the Development and Testing of Inorganic Sorbents task. Equipment modifications for converting hydrous titanium oxide microspheres to sodium titanate at elevated temperatures were completed. Three batches of hydrous titanium oxide microspheres embedded with fine particles of sodium titanate have been prepared using the internal gelation process.

Within the second research area-Reactor Fuel Chemistry-a new scope of work for the Technical Assistance in Review of Advanced Reactors task has been established to include assessments of iodine behavior and $\mathrm{pH}$ control in operating nuclear reactor containments as well as in advanced reactor systems. This task is on hold, awaiting finalization of the revised proposal and receipt of the necessary information from Westinghouse to permit the start of the study. 
Within the third research area-Thermodynamics - the Thermodynamics and Kinetics of EnergyRelated Materials task has used a differential thermal analysis (DTA)/thermogravimetric analysis (TGA) to study the phase transitions of phase-pure $\mathrm{YBa}_{2} \mathrm{Cu}_{3} \mathrm{O}_{6+x}(123)$ at partial oxygen pressures ranging from 1 to $10^{-4.3} \mathrm{~atm}$. Each sample of sintered 123 was allowed to equilibrate for $2 \mathrm{~h}$ at a temperature slightly below that of the first phase transition. The temperature of the 123 sample was increased at a rate of $1^{\circ} \mathrm{C}$ min until a temperature of $1295^{\circ} \mathrm{C}$ was reached. The temperatures (based on DTA results) of the two phase transitions - (1) $123 \rightarrow \mathrm{Y}_{2} \mathrm{BaCuO}_{5}(211)+$ liquid and (2) $211+$ liquid $\rightarrow$ liquid-were determined. Our current results for the $123 \rightarrow 211+$ liquid transition are in excellent agreement with $\mathrm{K}$. W. Lay's earlier study with a DTA/TGA system. Unfortunately, our results do not agree with those obtained by T. B. Lindemer in an earlier study. Efforts are under way to account for these discrepancies.

The fourth major research area-Processes for Waste Management-includes work on these tasks: Ion Exchange Process for Heavy Metals Removal, Hot Cell Cross-Flow Filtration Studies of Gunite Tank Sludges, and Chemical Conversion of Nitrate Directly to Nitrogen Gas: A Feasibility Study.

The first of these tasks-Ion Exchange Process for Heavy Metals Removal--involves the use of a transportable pilot-scale ion-exchange system to remove heavy metals from multiple sites using the most effective commercially available sorbent based on laboratory screening experiments. (This work is an extension of the Acid Mine Drainage Treatment Project.) The system will operate alongside three novel treatment systems and serve as baseline technology. The project is being run by the National Institute of Environmental Renewal. Construction of the systems was completed the first week of June, with equipment checkout and programming completed near the end of June. All instrumentation functioned properly, and modem communication with the machine was tested and confirmed. The demonstration trailer was shipped to the Tobyhanna Army Depot on June 26, 1996.

The mobilization of Gunite tank sludges and future MVST sludges requires reliable filtration as a first step in volume reduction. In the Hot Cell Cross-Flow Filtration Studies of Gunite Tank Sludges task, a bench-top, cross-flow filtration apparatus, placed in a hot cell, will filter actual Gunite tank sludges as part of an effort designed to study filtration and operational reliability. The Cell Unit Facility unit was received from Savannah River and tested with surrogate sludge outside the hot cell. Following a number of modifications to the unit, it was placed inside the hot cell; a final operational check is in progress. Operational tests with Gunite sludge composites are expected to be completed next quarter.

As part of the final task within this area-Chemical Conversion of Nitrate Directly to Nitrogen Gas- a bench-top feasibility study to convert nitrate directly to nitrogen gas utilizing aluminum metal with amalgamated surfaces is in preparation. The experimental equipment for processing $200 \mathrm{~mL}$ of 4 $M$ nitrate-based solution has been set up and a safety review completed. Tests of the principle involved are expected to be conducted next quarter. 


\title{
1. CHEMICAL PROCESSES FOR WASTE MANAGEMENT
}

\author{
B. Z. Egan
}

1.1 COMPREHENSIVE SUPERNATE TREATMENT (J. L. Collins, K. K. Anderson, and B. Z. Egan)

Contact: B. Zane Egan

Telephone: (423) 574-6868

Internet: eganbz@ornl.gov

Summary: A small-column test was conducted using Reillex HPQ anion-exchange resin to measure the removal of pertechnetate from Oak Ridge National Laboratory (ORNL) Melton Valley Storage Tank (MVST) W-27 supernatant. The fractions from the small-column test were analyzed by inductively coupled plasma-mass spectroscopy ICP-MS to determine technetium content. The $50 \%$ technetium breakthrough occurred at about 45 bed volumes (BV). The technetium was eluted in about $7 \mathrm{BV}$ of eluent using a solution containing $0.017 \mathrm{M}$ stannous chloride, $0.1 \mathrm{M}$ ethylenediamine, and $0.075 \mathrm{M}$ sodium hydroxide.

A second small-column test using Eichrom ABEC-5000-XL anion-exchange resin to remove pertechnetate from ORNL MVST W-27 supernatant was also completed. Samples from this test are being analyzed for technetium using ICP-MS.

\subsubsection{Purpose and Scope}

This task involves testing sorbent materials for removing cesium, strontium, and technetium from the saline solutions in U.S. Department of Energy (DOE) storage tank supernatant at Oak Ridge and other sites. Batch tests are used to evaluate and select the most promising materials for supernatant treatment to reduce the amount of waste for final disposal. Small-column tests are made on selected sorbents to verify the batch data and to obtain additional data for process design. Methods will be evaluated for recovering the radionuclides from the sorbents.

Supernatants used in the tests have been retrieved from MVST W-25, W-27, and W-29. These supernatants have many similarities to supernatants in tanks at other DOE sites. Efforts will be made to obtain samples of tank supernatants from Hanford for comparison. Many of the sorbents have been proposed for waste treatment, but most have not been tested on actual waste solutions.

\subsubsection{Progress}

Reillex HPQ was selected for the first column run to measure the removal of pertechnetate from ORNL MVST W-27 supernatant. The supernatant was column effluent from which a large portion of the cesium had been removed. The supernatant was also filtered through a $0.45-\mu \mathrm{m}$ filter. The $\mathrm{pH}$ was 12.86. Because of the relatively low technetium content of the supernatant $(0.43 \mathrm{mg} / \mathrm{L})$, ammonium pertechnetate was added to the feed to adjust the concentration to $3.0 \mathrm{mg} / \mathrm{L}$. The $1.45 \mathrm{~cm}(\mathrm{ID}) \times 15 \mathrm{~cm}$ ion-exchange column containing Reillex HPQ was conditioned with a solution of $5.0 \mathrm{M}$ sodium nitrate and $0.16 M$ sodium hydroxide prior to beginning the run. 
The height of the preconditioned resin bed was $6.3 \mathrm{~cm}$, providing a packed bed of about $10.4 \mathrm{~cm}^{3}$. Supernatant solution was passed through the column at a rate of about $6 \mathrm{BV} / \mathrm{h}$. Eluate fractions were collected, and selected fractions were analyzed by ICP-MS to determine the technetium concentration. Results indicated a 50\% technetium breakthrough at about $45 \mathrm{BV}$. This corresponds to approximately $1.4 \mathrm{mg}$ of technetium loaded on the $6.97 \mathrm{~g}$ of resin at $50 \%$ breakthrough.

The column was washed with about $7 \mathrm{BV}$ of water before eluting the resin bed at a flow rate of $\sim 4 \mathrm{BV} / \mathrm{h}$ using an eluent solution containing $0.017 \mathrm{M}$ stannous chloride, $0.1 \mathrm{M}$ ethylenediamine, and $0.075 M$ sodium hydroxide. This eluent was developed and used successfully by N. C. Schroeder of Los Alamos National Laboratory for eluting technetium from Reillex HPQ. The technetium was readily removed from the column using this eluent. Approximately $1.2 \mathrm{mg}$ of technetium was eluted in $7 \mathrm{BV}$ of eluent. In one fraction, the technetium concentration was more than 40 times the concentration in the supernatant feed.

A small-column test using Eichrom ABEC-5000-XI resin to measure the removal of pertechnetate from ORNL MVST W-27 supernatant was also run. For preparation of a feed solution, an additional $5 \mathrm{~L}$ of MVST supernatant from tank W-27 that had been processed previously by D. D. Lee to remove most of the cesium was obtained. Most of the remaining cesium was removed by further batch treatments with crystalline silicotitanate and potassium cobalt hexacyanoferrate. The resulting supernatant was then filtered through a $0.2-\mu \mathrm{m}$ filter. Because of the relatively low technetium content of the supernatant $(0.43 \mathrm{mg} / \mathrm{L})$, feed solution for the ABEC-5000 column test was then prepared by adding $65 \mu \mathrm{Ci}$ of ${ }^{99} \mathrm{Tc}$ to $2 \mathrm{~L}$ of the treated supernatant to adjust the concentration to $3.0 \mathrm{mg} / \mathrm{L}$.

A Kontes glass column with an inside diameter of $1.45 \mathrm{~cm}$ was used. The resin, slurried in water, was added to give a bed height of $10.5 \mathrm{~cm}$, corresponding to a bed volume of $17.3 \mathrm{~mL}$. The resin was then washed with $3 \mathrm{BV}$ of $4 \mathrm{M} \mathrm{NaOH}$. This caused the bed height to shrink to $5.1 \mathrm{~cm}$. A solution containing $0.16 \mathrm{M} \mathrm{NaOH}$ and $4.5 \mathrm{M}$ sodium nitrate, simulating the feed solution, was added to the column, resulting in an increase in the bed height to $8.55 \mathrm{~cm}$. Once the treated MVST W-27 supernatant was added to the resin bed, the final bed height was $6.2 \mathrm{~cm}$, providing a packed bed of about $10.4 \mathrm{~cm}^{3}$. Supernatant solution was passed through the column at a rate of about $6.8 \mathrm{BV} / \mathrm{h}$. The ABEC-5000-XL resin floated in all the solutions except water. A special apparatus was used to maintain the bed during swelling and shrinkage.

About $1200 \mathrm{~mL}$ of supernatant was passed through the column, and 120 fractions were collected. The column was then washed with about $3 \mathrm{BV}$ of $2 \mathrm{MNaOH}$. To elute the technetium from the column, about $100 \mathrm{~mL}$ of water was passed through the column at an average flow rate of $5 \mathrm{BV} / \mathrm{h}$. Eluate 
fractions were collected, and selected fractions are currently being analyzed by ICP-MS to determine the technetium concentration.

The principal investigator participated in the Efficient Separations Processes Crosscutting Program (ESP) Midyear Review in Gaithersburg, Maryland, April 16-18, 1996.

\subsection{PARTITIONING OF SLUDGE COMPONENTS BY CAUSTIC LEACHING (B. Z. Egan, B. B. Spencer," J. L. Collins, D. D. Ensor,"* and C. W. Chase) \\ Contact: B. Zane Egan \\ Telephone: (423) 574-6868 \\ Internet: eganbz@ornl.gov}

Summary: Several tests to measure the caustic dissolution behavior of Hanford tank sludges have been completed. Two samples of Hanford tank S-104 sludge were leached with $3.9 \mathrm{MNaOH}$ at $70^{\circ} \mathrm{C}$ for 4 and $24 \mathrm{~h}$ to determine the effect of time on the dissolution behavior. Two other samples were leached with $3.9 \mathrm{M} \mathrm{NaOH}$ at $70^{\circ} \mathrm{C}$ for $21 \mathrm{~h}$ using different leachant-to-sludge ratios to determine if the dissolution behavior is governed by limited solubility of specific components. Additional caustic leach tests were completed on sludge samples from Hanford tanks S-104 and SX-113 leached with $6 \mathrm{MNaOH}$ at $70^{\circ} \mathrm{C}$ for $21 \mathrm{~h}$.

Preliminary results from the S-104 sludge indicate a kinetic effect in the caustic leaching. Neither liquid-to-solid ratios greater than 5 or caustic concentrations that had been increased from $4 M$ to $6 \mathrm{M}$ had a significant effect. Under identical conditions, the fraction of aluminum leached from SX-113 sludge was twice that leached from S-104 sludge.

\subsubsection{Purpose and Scope}

Many underground storage tanks contain high concentrations of nonradioactive materials such as aluminum, chromium, and phosphates that can significantly increase the volume of the final high-level waste (HLW) waste form for disposal. There is increasing emphasis on removing these materials through "Enhanced Sludge Washing," such as taking advantage of the solubility of these materials under very caustic conditions to partition the radioactive and nonradioactive components. The behavior of some of the components, such as chromium and phosphate, is also important to vitrification processes. An objective of this project is to measure the caustic dissolution behavior of sludge components from ORNL MVST sludge, surrogate Hanford sludges, and selected Hanford sludge samples. If the nonradioactive components can be preferentially solubilized, then the volume of the remaining radioactive waste to be treated and/or stored would be significantly reduced.

\footnotetext{
"Robotics and Process Systems Division, ORNL.

"*Tennessee Technological University, Cookeville, Tennessee.
} 


\subsubsection{Progress}

Several additional caustic washing or leaching tests on Hanford tank sludges have been completed. The tests were performed at an operating temperature of $70^{\circ} \mathrm{C}$ with a 24 -h contact time. Three tests on sludge from tank S-104 were done with $\sim 4 M \mathrm{NaOH}$ at liquid-to-solid ratios of approximately $5,7.5$, and $10 \mathrm{~mL} / \mathrm{g}$. A previous test using a liquid-to-solid ratio of 7.5 also provided data for a 4-h contact time. A fourth test on S-104 sludge was completed using a liquid-to-solid ratio of 10 and a caustic concentration of $\sim 6 \mathrm{MNaOH}$. One test was performed with SX-113 sludge at a liquid-tosolid ratio of 10 and a caustic concentration of $\sim 6 \mathrm{M} \mathrm{NaOH}$. The residual solids, leachates, and rinse solutions from each test were analyzed for the constituents found in the original sludge.

Analyses were completed of the liquid and solid samples derived from leaching tests in which two 3-g samples of Hanford sludge from tank S-104 were mixed with $24 \mathrm{~mL}$ of $3.9 \mathrm{MNaOH}$ at $70^{\circ} \mathrm{C}$ for 4 and $24 \mathrm{~h}$. In these tests the leached sludge solids were also washed three times with a solution containing $0.01 \mathrm{M}$ sodium hydroxide and $0.01 \mathrm{M}$ sodium nitrite. Analyses of the residues, leachates, and wash solutions showed that both of the tests removed about $98 \%$ of the ${ }^{137} \mathrm{Cs}, 98-99 \%$ of the chromium, and $>80 \%$ of the sodium. These components, along with aluminum, are the major constituents in the sludge. Increasing the mixing time from 4 to $24 \mathrm{~h}$ increased the removal of aluminum from 35 to $51 \%$. Based upon residue analysis, other components that showed significant solubility included $\mathrm{Cu}, \mathrm{K}, \mathrm{Mn}$, and $\mathrm{Fe}$. Smaller amounts of $\mathrm{Ca}, \mathrm{Mg}, \mathrm{Bi}$, and $\mathrm{Ni}$ were removed. Since $\mathrm{Fe}, \mathrm{Mn}, \mathrm{Ni}$, and $\mathrm{Cu}$ were present in relatively small amounts in the sludge, those results are being evaluated further.

Also, caustic leaching tests with samples of Hanford sludge from tank S-104 were completed in which 1.5 and $3.0 \mathrm{~g}$ were mixed with $16-\mathrm{mL}$ volumes of $3.98 \mathrm{M} \mathrm{NaOH}$ for $21 \mathrm{~h}$ at $70^{\circ} \mathrm{C}$. The solid residues were washed four times with $16-\mathrm{mL}$ volumes of a solution containing $0.01 \mathrm{M}$ sodium hydroxide and $0.01 M$ sodium nitrite to remove the interstitial leachate. The leachates and cumulative washes along with the residues were analyzed for both radioactive and nonradioactive components. Good mass balances were not obtained with some components, and the reasons for this behavior are being studied. Similar behavior has been noted in sludge dissolution studies at other sites.

Two additional caustic leaching tests with samples of Hanford sludge from tanks S-104 and SX-113 were completed. About $1.5 \mathrm{~g}$ of each sludge sample was mixed with $15-\mathrm{mL}$ volumes of $6.27 M$ $\mathrm{NaOH}$ at $70^{\circ} \mathrm{C}$ for $21 \mathrm{~h}$. These conditions were chosen to increase the removal of components from the sludge. The solid residues were washed three times with an "inhibited water" solution containing $0.01 \mathrm{M}$ sodium hydroxide and $0.01 \mathrm{M}$ sodium nitrite to remove the interstitial leachate. The weights of the leachates, wash solutions, and residues were determined. The leachates and cumulative washes, along 
with the residues, are being analyzed for radioactive and nonradioactive components. Preliminary gamma-counting data indicated that much less cesium was removed from the SX-113 sample, possibly due to sorption on the diatomaceous earth in this tank.

Material balances for some species, such as silicon and phosphorus, are poor and indicate either difficulty in analysis or reprecipitation prior to sampling. For other materials, such as aluminum and chromium, the material balances are much better, and the effect of caustic leaching may be described with more confidence. Preliminary results indicate that (1) increasing contact time increases the amounts of aluminum removed from the sludge; (2) the liquid-to-solid ratio, over the range tested, does not significantly affect the removal of metals from the sludge; and (3) increasing the caustic concentration from $4 M$ to $6 M$ has no significant effect. Different sludges have been shown to react to treatment much differently. For example, under identical conditions the fraction of aluminum leached from SX-113 sludge is twice that leached from S-104 sludge. Additional experiments are planned, and data analysis is continuing. Analytical procedures have been modified in attempts to improve the material balance values.

\subsection{STUDIES ON TREATMENT OF DISSOLVED MVST SLUDGE USING TRUEX PROCESS (B. B. Spencer* and C. W. Chase)}

Contact: Barry B. Spencer

Telephone: (423) 574-7143

Internet: spencerbb@ornl.gov

Summary: Preparation of an ORNL/TM report on the transuranium extraction (TRUEX) tests performed with disssolved MVST sludge continued as a low-priority effort. The report is about $85 \%$ complete.

\subsubsection{Purpose and Scope}

The focus of this experimental program is to evaluate the TRUEX solvent extraction process for partitioning actinides from actual HLW sludge dissolved in nitric acid. A large sludge sample, previously removed from MVST W-25, has been well characterized and was available for the test program. The experimental phase of the evaluation program included dissolving portions of this sludge in nitric acid, followed by batch liquid-liquid equilibrium tests of both the extraction and stripping operations. Chemical analyses of both phases are used to evaluate the process. Evaluation is based on two metrics:

\footnotetext{
"Robotics and Process Systems Division, ORNL.
} 
the fraction of transuranic elements removed from the dissolved sludge and comparison of the results with predictions made with the Generic TRUEX Model (GTM).

\subsubsection{Progress}

Work to document the TRUEX tests performed with dissolved MVST sludge continued as a lowpriority effort. The GTM was used to simulate the experiments that were performed in the laboratory. The calculations were compared with the experimental results. The resulting report is about $85 \%$ complete.

A paper entitled "Thermodynamics of Extraction Equilibria Between $O \phi D(i B) C M P O-n$ Dodecane and Aqueous Nitric Acid Media. I. Nitric Acid" was completed and submitted for publication in the open literature.

\subsection{ACT ${ }^{\star D E}{ }^{\star}$ CON $^{\text {SM }}$ PROCESS TEST PROGRAM (B. B. Spencer and C. W. Chase)}

Contact: Barry B. Spencer

Telephone: (423) 574-7143

Internet: spencerbb@ornl.gov

Summary: The report Evaluation of the $A C T^{*} D E^{*} C O N^{s M}$ Process for Treating Gunite Tank Sludge, ORNL/TM-13201, was completed and published in May.

\subsubsection{Purpose and Scope}

The ACT*DE*CON ${ }^{\mathrm{SM}}$ process, a proprietary process of Selective Environmental Technologies, Inc. (Selentec), is designed to remove actinides from soils or soil-like media. The process is proposed as an alternative for removal of actinides from tank-stored $\mathrm{HLW}$ sludges. The $\mathrm{ACT}{ }^{*} \mathrm{DE}{ }^{*} \mathrm{CON}^{\mathrm{SM}}$ solvent is an aqueous carbonate solution containing a chelating agent and an oxidant. This combination of chemicals is rather benign and is intended to leach specific metal species from a soil matrix without destroying the bulk of the soil. The objective of the test program is to evaluate the $A C T^{*} D^{*} C^{5} N^{S M}$ process for pretreating Gunite and associated tank sludge as part of the sludge-processing flow-sheet development effort.

\subsubsection{Progress}

A report describing the results of a test to evaluate the proprietary $A C T^{*} \mathrm{DE}^{*} \mathrm{CON}^{\mathrm{SM}}$ process for selectively removing actinides from Gunite tank sludge was completed. Evaluation of the $A C T^{*} D E^{*} C O N^{N M}$ Process for Treating Gunite Tank Sludge, ORNL/TM-13201, was published in May. 


\title{
1.5 HOT DEMONSTRATION OF PROPOSED COMMERCIAL NUCLIDE REMOVAL TECHNOLOGY (D. D. Lee and J. R. Travis)
}

\author{
Contact: D. D. Lee \\ Telephone: (423) 576-2689 \\ Internet: Leedd@ornl.gov
}

Summary: This task covers work in the continuous removal and concentration of radioactive components from supernatants at the various DOE sites. The primary objective is to test candidate absorbers and ion exchangers under continuous-flow conditions using actual supernatant from the MVSTs. An experimental system contained in a hot-cell facility is used to test the materials in columns or modules using the same batch of supernatant so that they can all be compared on the same basis. During the last quarter, SuperLig $644 \mathrm{C}$ and the resorcinol/formaldehyde (RF) resins were tested. The $\mathrm{RF}$ resin was tested at a feed concentration of $5.5 \mathrm{M}$ sodium, $1 \mathrm{M}$ hydroxide, and $1 \times 10^{-5} \mathrm{M}$ cesium. The SuperLig resin was tested for one loading at the above concentrations and for three loadings at a cesium concentration of $7 \times 10^{-5} \mathrm{M}$. The same resin was loaded and eluted four times. Batch tests were also conducted to help determine the tank and adjustment requirements for the Cesium Removal Demonstration Project (CsRD) using the IONSIV 911 crystalline silicotitanate (CST).

\subsubsection{Purpose and Scope}

This task involves the operation of an experimental test unit that is located in a Building 4501

hot cell. This equipment is designed to test radionuclide removal technologies under continuous operation on ORNL MVST supernatant, Savannah River HLW supernatant, and Hanford supernatant. The latter two may be simulated by adding the appropriate chemicals and/or nuclides to the MVST supernatant. This unit provides a test bed for investigating new technologies that become available during this program and complements the comprehensive supernatant task by using larger engineering-scale, continuous equipment to verify and expand the batch studies. It also complements the Tank Focus Area's (TFA's) CsRD at Oak Ridge by providing sorbent-selection information, evaluation and testing of proposed sorbents, and operational experience and characteristics using the sorbent and supernatant to be used in the demonstration.

There is close cooperation with the ESP and the TFA in order ultimately to transfer the technologies being developed to the end user. TFA requested (through ESP) that ORNL test AEA Technology's electrodialysis/ion-exchange (ED/X) system as part of this ESP project because ORNL was the only site with sufficient supernatant available for testing the multiple-cycle ED/XX system.

Initial candidate sorbents for cesium removal were the RF resin, CSTs, SuperLig® 644C resin, 3M WWL 644 WEB material with SuperLig(B 644 embedded, Rohm \& Haas CS-100 resin, and granular potassium cobalt hexacyanoferrate. The results of these tests will be compared with batch results and small-column tests results obtained in the Comprehensive Supernatant Treatment Task (B. Z. Egan). The results are being used to supply the CsRD (J.F. Walker) with the information to determine the design 
parameters and sorbent for that project. The rate of removal, resin required, and regeneration requirements are important design parameters; and the loading capacity of each sorbent will help to determine the size of the column required and help define the final volume of solid waste to be disposed of.

\subsubsection{Progress}

Two ion-exchange material tests were completed in Hot Cell $\mathrm{C}$ during the third quarter of FY 1996. The feed supernatant for the tests was obtained from MVST W-27 in April 1995. Tank W-27 contains supernatant at pH 7.2 and has the lowest potassium and ${ }^{137} \mathrm{Cs}$ levels of the available tanks. This supernatant was adjusted to $\mathrm{pH} 14.0$ ( $1 M$ hydroxide concentration), and runs were completed with and without cold cesium added to provide a total cesium concentration of either $1 \times 10^{-5}$ or $7 \times 10^{-5} \mathrm{M}$.

\subsubsection{Superlig $^{\circledast 6} 644 \mathrm{C}$ at $1 \mathrm{NHydroxide}$ and $3.5 \mathrm{CV} / \mathrm{h}$}

The SuperLig ${ }^{\circ}$ for this run was prepared by measuring $4.657 \mathrm{~g}$ of dry resin into a column (6.2 $\mathrm{mL}$ packed dry), treating as in the previous run (wetting with deionized water, followed by $2 \mathrm{~N}$ $\mathrm{NaOH}$ ), and then treating with a feed surrogate made to $5 \mathrm{NNaNO}_{3}$ and $1 \mathrm{~N} \mathrm{NaOH}$. This run used the W-27 feed made to $\mathrm{pH} 14$ and was planned to be a multiple load and elute experiment in which the cesium was loaded and then eluted with $0.5 \mathrm{~N} \mathrm{HNO}_{3}$ and the resin regenerated with $2 \mathrm{~N} \mathrm{NaOH}$ and then reloaded with the cesium in the W-27 feed. For this set of runs, the first loading was done with the normal amount of cesium in the feed $\left(1.1 \times 10^{-5} \mathrm{M}\right)$, and the following three were done with approximately seven times as much cesium (in the form of cold cesium added as cesium nitrate), giving a measured total of about $7.5 \times 10^{-5} \mathrm{M}$ cesium in the feed. The loading was done at a flow rate of 3.5 column volumes (CV)/h in downflow. The flow rate was determined by measuring the resin bed volume during the loading process after several column volumes of supernatant had passed through the bed and the volume had stabilized. Because of the low density of the SuperLig ${ }^{\mathbb{B}} 644$ in the $5 M$ salt solution, a special weighted bed follower, developed by J. L. Collins, was used to keep the bed packed during loading, elution, and regeneration, when the bed volume changed by up to $40-50 \%$. For example, the loading took place with the bed at $10.3 \mathrm{~cm}^{3}$, the water rinse of the bed after loading increased the volume to $13.0 \mathrm{~cm}^{3}$, and elution of the bed reduced the volume to $8.6 \mathrm{~cm}^{3}$.

The first loading used $\mathrm{pH} 14$ feed with $1.1 \times 10^{-5} \mathrm{M}$ cesium and a flow rate of $3.5 \mathrm{CV} / \mathrm{h}$ with a column volume of $10.2 \mathrm{~cm}^{3}$ and an ambient temperature of $28^{\circ} \mathrm{C}$. The initial flow of supernatant through the column produced a reddish-brown color that gradually decreased over about $2 \mathrm{CV}$. The color could 
be followed all the way to the fraction collector. Some discoloration of the downstream filter with a pinkcolored material was also noted, but no plugging occurred. The cesium breakthrough was first seen when less than $10 \mathrm{CV}$ had passed through the bed. The loading continued until about $60 \%$ breakthrough was indicated by the on-line detector with $50 \%$ breakthrough occurring at about $167 \mathrm{CV}$. The column was then rinsed with deionized water and prepared for the elution. The rinse expanded the bed to a volume of $12.9 \mathrm{~cm}^{3}$ and also resulted in some color being released from the column.

The elution was completed using downflow through the bed with $0.5 \mathrm{NHNO}_{3}$ at approximately the same flow rate as the loading and based on the loading volume. As soon as acid began flowing through the bed, it began to shrink After about $3 \mathrm{CV}$ passed through the bed, the volume had decreased to $10 \mathrm{~cm}^{3}$ and finally decreased to $9.5 \mathrm{~cm}^{3}$ by the end of the elution. A total of $90 \mathrm{~mL}$ of acid was used in the elution. The in-line detector curve flattened at about $5 \mathrm{C} / \mathrm{C}_{0}$, where the detector is completely saturated and will not record higher readings. Fractions collected during the elution were analyzed to develop the total elution curve, with the peak occurring at about $36 \mathrm{C} / \mathrm{C}_{0}$ at $4 \mathrm{CV}$ of acid. The column was rinsed with deionized water following the elution, with the water remaining in the column until the regeneration.

The column was regenerated with $50 \mathrm{~mL}(5 \mathrm{CV})$ of $2 \mathrm{~N} \mathrm{NaOH}$ in upflow at a $0.5-\mathrm{mL} / \mathrm{min}$ flow rate. The bed was $9.2 \mathrm{~cm}^{3}$ at the start of regeneration. Color began coming off the bed as the first column volumes of regenerant passed through; this phenomenon continued for about $2 \mathrm{CV}$. The regeneration was continued with the final volume of the bed going to $11.9 \mathrm{~cm}^{3}$. The bed was then rinsed with $5 \mathrm{CV}$ of the surrogate salt solution and readied for the next loading. During the salt rinse, it was noted that many small bubbles had formed throughout the bed; efforts were initiated to remove them. This was done by applying a vacuum to the bed and suddenly releasing it. A series of four cycles was completed, and the bed was reduced to a volume of $10.5 \mathrm{~cm}^{3}$ for the start of loading. No bubbles could be seen after the treatment.

The next loading was completed using feed that had cold cesium added to give a total cesium concentration of $7.5 \times 10^{-5} \mathrm{M}$ with the $\mathrm{pH}$ still at 14 and other concentrations remaining the same. Feed to the column was again at $3.5 \mathrm{CV} / \mathrm{h}$, and slight color was seen as the feed initially passed through the bed but disappeared after about $3 \mathrm{CV}$. Breakthrough of the cesium was almost immediate. Whether this was due to incomplete elution and regeneration or to flow distribution problems in the bed caused by the bubble removal process has not been determined. The loading curve was approximately parallel to the first curve, but the $50 \%$ breakthrough occurred at $77 \mathrm{CV}$. Deionized water was used for the rinse, and 
the column was prepared for the elution. The bed volume at the end of the supernatant feed was $10.2 \mathrm{~cm}^{3}$ and expanded to $12.7 \mathrm{~cm}^{3}$ following the rinse.

The elution was conducted the same as the previous one, but a total of $12 \mathrm{CV}(120 \mathrm{~mL})$ acid was used. The elution curve was displaced about $2 \mathrm{CV}$ to the right from the first elution curve, with the peak of $15 \mathrm{C} / \mathrm{C}_{0}$ occurring at about $5.5 \mathrm{CV}$. Some brown color came off the bed in the first few column volumes, and the bed shrank to $8.7 \mathrm{~cm}^{3}$ by the end of the elution. Small bubbles were seen at the bottom of the bed after about $3 \mathrm{CV}$, and more bubbles began to appear on the sides and near the top as the elution continued. The bubbles increased in size and became more numerous until the elution was finished.

Before the regeneration was attempted, the bubbles were removed by again applying a vacuum/release sequence to the bed. When this was completed, the column volume was $8.4 \mathrm{~cm}^{3}$. The regeneration was started in upflow at about $3 \mathrm{CV} / \mathrm{h}$ with the $2 \mathrm{~N} \mathrm{NaOH}$. As in the first regeneration, a reddish-colored band that grew fainter and disappeared within the first two column volumes came off the column. During this time a few solids could be seen below the filter and in some of the lines. The final volume after regeneration was a false low reading. When the run was ended at about $25 \%$ breakthrough, the curve was extrapolated to the $50 \%$ point to give a $50 \%$ breakthrough of about $65 \mathrm{CV}$. The column was then rinsed with deionized water and the bed expanded to $13 \mathrm{~cm}^{3}$. No bubbles were seen during the loading or rinse.

The elution was preceded with a 5-CV rinse with deionized water to try to prevent bubble formation. A lot of color was seen during the first flow of the deionized water through the bed. The elution was completed with over $8 \mathrm{CV}$ of $0.5 \mathrm{NHNO}_{3}$ and resulted in a peak of $14 \mathrm{C}^{\mathrm{C}} \mathrm{C}_{0}$ in the effluent at $3 \mathrm{CV}$ of eluent. During the elution, the bed shrank from 13 to $8.4 \mathrm{~cm}^{3}$. After the elution was completed, the column was rinsed with deionized water, with no volume change in the column.

Regeneration prior to the fourth loading was completed in downflow (upflow was used in the first three regenerations) using $\sim 10 \mathrm{CV}$ of $2 \mathrm{~N} \mathrm{NaOH}$. Color left the bed almost immediately and continued for about $2 \mathrm{CV}$, and the bed expanded to $11.5 \mathrm{~cm}^{3}$. The salt surrogate was then pumped through the column and resulted in a bed volume of $10.9 \mathrm{~cm}^{3}$. No bubbles were seen during any of these operations, and no vacuum sequence was used before the fourth loading.

The fourth loading was begun at $3.5 \mathrm{CV} / \mathrm{h}$ and resulted in color leaving the column again but not as much as in previous loadings. The bed volume also decreased slightly to $10.5 \mathrm{~cm}^{3}$ during the loading. The loading curve started up at a steep slope right away but gradually decreased in slope through the 5to $10-\mathrm{CV}$ range and became almost parallel to that of the second loading by the time the $50 \%$ breakthrough point was reached at about $50 \mathrm{CV}$. The column was rinsed with deionized water following 
the loading, and the bed expanded to $13 \mathrm{~cm}^{3}$ during the rinse. The three loadings that exceeded $50 \%$ showed an increase in slope as the curves passed $40-45 \%$ breakthrough. The slope change was detected both on the in-line detector and in the fractions that were analyzed later.

The column was rinsed and then eluted as in the previous loadings. Before the elution was started, a 3-CV rinse with deionized water was concluded. An extra amount (11 CV) of acid was used to try to remove most of the cesium from the column. The curve was very similar to the third elution with the peak at about $3 \mathrm{CV}$ and a concentration of $13 \mathrm{C} / \mathrm{C}_{0}$ in the effluent. During the elution, the bed decreased to a volume of $8.4 \mathrm{~cm}^{3}$ and stayed at that volume during a rinse with deionized water. The column was then drained and removed from the system and stored for later reuse or additional analysis. A count of the column showed that $5.2 \mu \mathrm{Ci}$ of ${ }^{137} \mathrm{Cs}$ (equivalent to about $0.5 \mathrm{~mL}$ of supernatant) was left on the column. In addition, ${ }^{60} \mathrm{Co}$ and ${ }^{106} \mathrm{Ru}$ were concentrated on the resin, with the cobalt equivalent to almost $500 \mathrm{~mL}$ of supernatant remaining and $0.11 \mu \mathrm{Ci}$ of ruthenium present. The amount of ruthenium in the feed supernatant was below the detection limits.

\subsubsection{RF Resin at $1 \mathrm{NHydroxide}$ and $3.5 \mathrm{CV} / \mathrm{h}$}

An experiment was completed using RF resin obtained from the Radiochemical Engineering Development Center (REDC) at ORNL (Bibler resin from W. Bond, currently in use at the REDC) of $-60+80$ mesh size, in which the feed rate through the bed was $3.5 \mathrm{CV} / \mathrm{h}$. Three previous experiments were completed with resin obtained from Bibler and supernatant at $0.1 \mathrm{~N}$ hydroxide concentration. For this run, $6.029 \mathrm{~g}$ of resin (tapped volume, $8.3 \mathrm{~cm}^{3}$ ) was treated with $10 \mathrm{CV}$ of $0.5 \mathrm{MHNO}_{3}$, followed by $7 \mathrm{CV}$ of deionized water. During this treatment, the bed volume decreased to $7.3 \mathrm{~cm}^{3}$. The bed was then treated with $2 \mathrm{MNaOH}$ for $10 \mathrm{CV}$ at the expanded volume of resin and rinsed with deionized water for $3 \mathrm{CV}$. The resin expanded to $13.86 \mathrm{~cm}^{3}$ during caustic treatment. Approximately $10.7 \mathrm{~cm}^{3}$ of the resin was placed in the 1.5-cm-ID test column and had a bed height of $6.5 \mathrm{~cm}$. The weighted bed follower described previously was also used during this run. The column was filled with a surrogate salt solution of $5 \mathrm{NNaNO}_{3}$ and $1 \mathrm{NNaOH}$ in preparation for loading.

The column was installed as previously described. Supernatant feed was started through the bed at $3.5 \mathrm{CV} / \mathrm{h}$. This supernatant was also used for the first SuperLig loading in the multiple-loading run $\left(1 \times 10^{-5} \mathrm{M}\right.$ cesium). Once feed was started through the bed, the effluent became brown and remained that color for 2 to $3 \mathrm{CV}$; the dark color could be seen as the effluent passed through the tubing and filter. During the first $4 \mathrm{CV}$ of feed through the bed, the bed volume increased to about $11.1 \mathrm{~cm}^{3}$ and remained at that level for the rest of the loading. During the run, there was difficulty maintaining a constant flow 
rate due to bubbles arising in the lines and migrating to the column pump. The loading was continued to a $70 \%$ breakthrough of the cesium. The initial breakthrough did not occur until $7 \mathrm{CV}$, and the curve was then very steep to $50 \%$ at about $20 \mathrm{CV}$. The column was rinsed with several column volumes of deionized water following the loading in preparation for the elution.

The $\mathrm{RF}$ resin was eluted using $0.5 \mathrm{~N} \mathrm{HNO}_{3}$ in downflow at about $3.5 \mathrm{CV} / \mathrm{h}$. The bed started at a volume of $12.9 \mathrm{~cm}^{3}$ after the previous loading and water rinse and ended at a volume of $9.1 \mathrm{~cm}^{3}$ after elution and rinse. A peak of about $3.4 \mathrm{C} / \mathrm{C}_{0}$ accurred at about $6 \mathrm{CV}$ of eluent. The curve is very broad and does not return to the baseline after $12 \mathrm{CV}$. After the elution and rinse were complete, the column was drained and removed from the system to storage.

\subsubsection{Batch Tests of the UOP IONSIV IE-911 CST}

The following describes the results for batch tests of the UOP IONSIV IE-911 CST material (lot no. 999096810001 ) to be used in the CsRD. The tests are designed to help select the supernatant to be used in the CsRD. The supernatant selected would then be transferred to the feed tank (W-29) for the operation of the demonstration. Tank W-29 contained a heel of liquid and a layer of solids from the previous operations using the tank. Tank W-29 is the same feed tank used during the solidification campaigns.

Tank W-29 has been estimated to contain approximately 11,000 gal of liquid above a sludge layer. The present cesium concentration in $\mathrm{W}-27$ is $3.3 \times 10^{5} \mathrm{~Bq} / \mathrm{mL}$. By calculation, the mixture of W-27/W-29 should produce a cesium concentration of $5.1 \times 10^{5} \mathrm{~Bq} / \mathrm{mL}$, and the mixture of W-31/W-29 should produce a concentration of $6.1 \times 10^{5} \mathrm{~Bq} / \mathrm{mL}$ based on the available analyses of the contents of the W-29 and W-31.

Based on that analysis, the estimate of the amount of supernatant that would be pumped into the W-29 tank for use in the CsRD is $\sim 22,000$ gal, producing a level of about $90 \%$ of the total available volume in the 50,000-gal tank. The CsRD will use up to $25,000 \mathrm{gal}$ of the W-29 supernatant for the test. Based on these estimates, a 2:1 ratio of W-27/W-29 and a 2:1 ratio of W-31/W-29 were selected to produce feed material for the batch tests with CST. The two tanks that can be used in the CsRD are W-27 and W-31. Tank W-27 supernatant has been used in the characterization and sorbent-selection tests conducted to date. It is fairly low in ${ }^{137} \mathrm{Cs}$, low in most RCRA metals, and well characterized. Tank W-31 is supposed to contain higher levels of ${ }^{137} \mathrm{Cs}$, has $\sim 10 \mathrm{ppm}$ chrome ( $5 \mathrm{ppm}$ is the RCRA limit), and is at a pH of $\sim 11.9$, compared with W-27 at a pH of $\sim 7.4$. Tank W-27 also contains more cold cesium 
than the fission product yield alone would predict, and the values of total cesium in W-29 and W-31 are not known accurately at this time.

The supernatant from MVST tank W-29 used for the batch test series was obtained from the Building 2026 Analytical Services samples that had been sent for analysis by David Van Essen for the Out-of-Tank Evaporator Test completed in March and April of 1996. A total of six bottles of the evaporator feed were sampled (7-8 mL per bottle), resulting in a composite of approximately $45 \mathrm{~mL}$. This sample was transferred to Building 4501 for use in the batch contact tests.

The $\mathrm{pH}$ of the W-29 composite was confirmed by titration to the phenothalein endpoint to be about 13.44 ( $1 \mathrm{~mL}$ of $\mathrm{W}-29$ required $2.80 \mathrm{~mL}$ of $0.1 \mathrm{~N} \mathrm{HCl}$ for neutralization). To make the feed mixtures for the batch tests, $20 \mathrm{~mL}$ of W-29 sample was mixed with $40 \mathrm{~mL}$ of W-27 sample, and $20 \mathrm{~mL}$ of W-29 was mixed with $40 \mathrm{~mL}$ of the W-31 sample. The W-27 and W-31 samples were archived samples obtained in December of 1994 and stored in Building 4501 since that time. For comparison, a 60-mL sample of $\mathrm{W}-27$ was also submitted to the same set of batch tests.

The batch feeds were checked for $\mathrm{pH}$ after mixing (the $\mathrm{W}-27$-only feed was adjusted first by adding $1.431 \mathrm{~g}$ of $\mathrm{NaOH}$ pellets and mixing), with the $\mathrm{pH}$ of the $\mathrm{W}-31 / \mathrm{W}-29$ mixture titrating to 13.08 , the W-29/W-27 mixture at 11.20, and the W-27-only feed at 12.95. The W-29/W-27 mix was adjusted by adding $0.204 \mathrm{~g}$ of $\mathrm{NaOH}$ and the $\mathrm{pH}$ checked again, resulting in a $\mathrm{pH}$ of 12.30 . An additional $0.191 \mathrm{~g}$ of $\mathrm{NaOH}$ was added, resulting in a final $\mathrm{pH}$ of 12.76 for the mix.

When the W-29 and W-31 were mixed, no precipitation occurred either initially or after standing overnight. When W-29 and W-27 were mixed, an immediate precipitation occurred consisting of a whitish-fluffy, slow-settling material occurred. When $\mathrm{NaOH}$ was added to the $\mathrm{W}-27$ sample, immediate precipitation also occurred, with considerably more volume and slower settling than the W-27/W-29 mix. After overnight settling, the W-27/W-29 mix had a total liquid height of $25 \mathrm{~mm}$ and a sludge layer height of $5 \mathrm{~mm}$. The W-27-only sample had a total height of $26 \mathrm{~mm}$ and a sludge layer of $9 \mathrm{~mm}$. After adding the extra $0.4 \mathrm{~g}$ of $\mathrm{NaOH}$ for $\mathrm{pH}$ adjustment to the W-27/W-29 mix, the solids were still fluffy but settled rather quickly (5-10 min produced a clear layer more than half of the total depth).

The two feeds with solids were filtered to produce a clear liquid for the batch tests using $0.45-\mu \mathrm{m}$ syringe filters giving a total of $\sim 45 \mathrm{~mL}$ of each. To determine the ${ }^{137} \mathrm{Cs}$ activity in the feed samples, a 0.5 -mL sample was removed from each feed bottle for analysis by gamma spectroscopy. The results are shown in Table 1. 
Table 1. Comparison of potential MVST feed mixtures for the Cs Removal Demonstration

\begin{tabular}{lcccccc}
\hline Supernatant & $\begin{array}{c}\text { Hydroxide, } \\
\boldsymbol{M}\end{array}$ & $\mathbf{p H}$ & $\begin{array}{c}{ }^{137} \mathbf{C s}, \\
\mu \mathrm{Ci} / \mathbf{m L}\end{array}$ & $\begin{array}{c}{ }^{134} \mathbf{C s}, \\
\mathbf{C i} / \mathbf{m L}\end{array}$ & $\begin{array}{c}\text { Ratio, } \\
\mathbf{1 3 7 / 1 3 4}\end{array}$ & $\begin{array}{c}\text { Density, } \\
\mathbf{g} / \mathbf{c m}^{3}\end{array}$ \\
\hline W-27 (adj.) & 0.089 & 12.95 & 10.07 & 0.0435 & 132 & 1.268 \\
W-27/W-29 & 0.057 & 12.76 & 15.53 & 0.376 & 41.3 & 1.240 \\
W-31/W-29 & 0.121 & 13.08 & 18.046 & 0.536 & 33.7 & 1.238 \\
\hline
\end{tabular}

These results are consistent with estimates based on the mixing of the supernatants using the analyses for the December 1994 samples for $\mathrm{pH},{ }^{137} \mathrm{Cs},{ }^{134} \mathrm{Cs}$, and density (with the W-29 analyses based on the W-24 supernatant that was later transferred to W-29).

The batch tests were designed to give an estimate of the performance of the UOP IONSIV IE-911 CST material with each of the two tank mixes and a comparison with the W-27 used in the resin-selection tests. Four liquid-to-solid ratios (10:1, 100:1, 500:1, and 1000:1) were used to cover a range of supernatant-to-CST ratios. The tests were set up as $\sim 18-\mathrm{h}$ batch shake tests with no intermediate sampling. The results are based on the amount of ${ }^{137} \mathrm{Cs}$ removed from the 5-mL solution during that time. The resin was also rinsed three times with water after the supernatant was removed, dried in air, and then counted to try to determine the specific activity of the ${ }^{137} \mathrm{Cs}$ loaded at the various liquid-to-solid ratios.

After the supernatant additions to the cones were completed, the cones with supernatant and CST were placed on a rocking contactor for the prescribed contact time. Two of the liquids were placed in cones without CST to check for supernatant/tube interaction. When contacting was complete, the tubes were removed and the liquid in each tube was withdrawn and placed into new cones. A sample of the liquid in each cone was then filtered and placed in a new cone. Finally, a sample of the filtered liquid was taken to determine by gamma spectroscopy the ${ }^{137} \mathrm{Cs}$ remaining in the solution. Two samples of each feed liquid were taken as well, for the initial concentration baseline. Samples of the unfiltered liquid from three of the cones containing the CST were also taken to determine if any of the CST had broken down and dissolved in the liquid during the sampling process. The solid CSTs left in the tubes were washed three times with water and then allowed to air dry before weighing and counting.

The results for the determination of the density of the feed materials are the average of five samples of $5 \mathrm{~mL}$ each. The densities are as follows: W-31/W-29-1.2380, W-27/W-29-1.2401, and W-27-1.2681. This agrees well with the predicted densities based on the December 1994 analyses on samples taken by Vic Fowler using W-24 analytical results for W-29. 
The counting results for the samples of liquid removed from each of the tubes containing CSTs were used as the basis for recommending that tank W-27 be used for the CsRD after it had been adjusted to $\mathrm{pH}>12.5$ using sodium hydroxide.

1.6 SLUDGE TREATMENT STUDIES (E. C. Beahm, S. A. Bush, C. F. Weber, T. A. Dillow, and R. D. Hunt)

Contact: E. C. Beahm

Telephone: (423) 574-6851

Internet: beahmec@ornl.gov

Summary: Test results from two Enhanced Sludge Washing sequences run on sludge from Hanford underground storage tank T-104 provided direct evidence that phosphate reprecipitated into the sludge residue-leachate mixture when the temperature was decreased from $75^{\circ} \mathrm{C}$ to ambient. This results in the formation of a gelatinous material that sticks to the walls of the container. The results show that phosphate solids will form if the correct leaching temperature is not maintained throughout the process.

\subsubsection{Purpose and Scope}

A particular objective of sludge treatment studies is to obtain a low-volume high-activity waste stream and a high-volume low-activity waste stream. Two aspects of sludge treatment should be well delineated and predictable: (1) the distribution of chemical species between aqueous solutions and solids and (2) potential problems due to chemical interactions that could result in process difficulties or safety concerns.

\subsubsection{Progress}

There are three ways to control Enhanced Sludge Washing so that it is effective in removing aluminum while avoiding the formation of gels or reprecipitation of solids in leachates or wash solutions: (1) precipitation control, (2) excess caustic, and/or (3) temperature control. Precipitation control requires specialized facilities and process operations such as seeding and filtration. Excess caustic involves the cost and handling of amounts of sodium hydroxide greater than that necessary to convert aluminum oxide hydroxide to the aluminate ion. While use of excess caustic will probably be required, temperature control will be a key factor in a successful Enhanced Sludge Washing process.

Two test sequences were carried out on sludge from Hanford underground storage tank T-104. In one test sequence, the temperature was $75^{\circ} \mathrm{C}$ throughout the process. In the other test sequence, the $75^{\circ} \mathrm{C}$ temperature was maintained only during leaching, and the process was then carried out at room temperature. The two tests were conducted in parallel to ensure that temperature was the only variable. 
There was a marked difference in the behavior of phosphate in the two tests. In the test in which the leachate was maintained at $75^{\circ} \mathrm{C}$ during settling and filtration, the amount of phosphate was approximately 10 times greater than in the leachate from the sequence in which the settling and filtration were performed at room temperature. This is direct evidence that the phosphate reprecipitated into the sludge residue-leachate mixture when the temperature was reduced to ambient, resulting in more phosphate in the sludge residue after leaching. This resulted in higher concentrations in the wash solutions at ambient temperature than in those at $75^{\circ} \mathrm{C}$. In the test sequence maintained at $75^{\circ} \mathrm{C}$, most of the phosphate remained in the leachate and was not present in the sludge residue at the time of washing.

There are several implications from these results. First, the temperature of the leachate enhanced the solubility of the phosphate. Second, leaching at an elevated temperature and then conducting the rest of the process at ambient temperature could possibly increase the rate of dissolution of phosphate, but reprecipitation would return the concentration to that consistent with room temperature. The reprecipitated phosphate is rather gelatinous and sticks to container walls. Third, if the correct leaching temperature is not maintained throughout the process, phosphate solids will form whenever it is lowered.

\subsection{DEVELOPMENT AND TESTING OF INORGANIC SORBENTS (J. L. Collins and K. K. Anderson) \\ Contact: J. L Collins \\ Telephone: $423-574-6689$ \\ Internet: Collinsjl@ornl.gov}

Summary: Several batches of hydrous titanium oxide microspheres have been prepared. Equipment modifications for converting hydrous titanium oxide microspheres to sodium titanate at elevated temperatures were completed. Three batches of hydrous titanium oxide microspheres embedded with fine particles of sodium titanate have been prepared using the internal gelation process.

\subsubsection{Purpose and Scope}

The general objectives of this task are to develop, prepare, and test new and unique inorganic ion exchangers made as microspheres by the internal gelation process to remove fission products, actinides, and other metals from waste streams occurring at various DOE sites. Initial emphasis will be on materials for removing radionuclides from supernatants from waste storage tanks.

Inorganic sorbents are being developed for removing strontium from aqueous waste and process streams. Attempts are being made to prepare pure sodium titanate microspheres, as well as composite microspheres consisting of hydrous titanium oxide or titanium monohydrogen phosphate embedded with 
fine powders of sodium titanate or silicotitanate. Two methods are being evaluated for conversion of hydrous titanium oxide microspheres to sodium titanate microspheres. One method involves heating the hydrous titanium oxide microspheres, prepared by the internal gelation process, with sodium hydroxide at elevated temperatures in a sealed reactor vessel. The other method involves an alkoxide conversion of the hydrous titanium oxide microspheres.

\subsubsection{Progress}

A Series 4532 Floor Stand Reactor made by the Parr Instrument Company was modified for use in the elevated-temperature conversions. A stainless steel mesh basket was built to hold the hydrous titanium oxide microspheres in the pressure vessel. The head of the reactor vessel was modified, and several special safety features were added. The thermowell and stirring assembly were adapted to allow the impellers to be positioned above the basket of microspheres to provide constant flow of the sodium hydroxide solution through the microspheres during the conversion process. Conversion tests will begin after the apparatus and procedures are approved.

Several batches of hydrous titanium oxide microspheres were prepared. Some of these materials will be used to evaluate two different schemes for conversion to sodium titanate and preparation of sodium titanate microspheres. Sodium titanate powders are being procured from several commercial sources. Materials will be selected for use in making hydrous titanium oxide/sodium titanate composite microspheres.

Sodium titanate was obtained as a slurry from Boulder Scientific Company. A portion of the sodium titanate slurry was placed in a blender equipped with stainless steel blades and blended at the highest speed for $30 \mathrm{~min}$. The blended material was then sieved through a 200 mesh $(75-\mu \mathrm{m}$ sieve openings) stainless steel sieve. The slurry of sodium titanate particles that passed through the sieve was centrifuged, and the liquid was removed by decantation. The wet, centrifuged sodium titanate particles had the consistency and appearance of toothpaste. Some samples were air dried to constant weight, and other samples were dried at $110^{\circ} \mathrm{C}$ for $24 \mathrm{~h}$. The ratios of the weights of the wet, centrifuged sodium titanate to the air-dried and oven-dried materials were 3.78 and 4.91 , respectively. A sample of the airdried sodium titanate was examined with a scanning electron microscope to determine the range of particle sizes. The diameter of the particles ranged from 0.9 to about $60 \mu \mathrm{m}$, with about $90 \%$ of the particles being in the $0.9-$ to $10-\mu \mathrm{m}$ range. About $60 \%$ of the particles had diameters of about $1 \mu \mathrm{m}$.

Conditions are being optimized to prepare composite microspheres containing the maximum amount of sodium titanate. Three batches of composite microspheres containing the sodium titanate 
powder embedded in hydrous titanium oxide were prepared using the internal gelation process. Broth mixtures were used that yielded microspheres having weight ratios of hydrous titanium oxide to sodium titanate (based on air-dried weights) of 9.9,6.6, and 4.9. The corresponding microspheres were calculated to contain about 9,13 , and $17 \%$ sodium titanate, respectively. Selected materials will be tested for removing strontium from aqueous waste solutions.

The principal investigator participated in the Efficient Separations Processes Crosscutting Program Midyear Review in Gaithersburg, Maryland, April 16-18, 1996.

\section{REACTOR FUEL CHEMISTRY}

\section{E. C. Beahm}

\section{TECHNICAL ASSISTANCE IN REVIEW OF ADVANCED REACTORS}

(E. C. Beahm and C. F. Weber)

Contact: E. C. Beahm

Telephone: (423) 574-6851

Internet: beahmec@ornl.gov

Summary: A new scope of work for this task has been established to include assessments of iodine behavior and $\mathrm{pH}$ control in operating nuclear reactor containments as well as in advanced reactor systems. This task is on hold, awaiting finalization of the revised proposal and receipt of the necessary information from Westinghouse to permit the start of the study.

\subsection{PURPOSE AND SCOPE}

The objective of this project is to provide assistance to the U.S. Nuclear Regulatory Commission (NRC) staff in reviewing the four advanced reactor designs submitted under 10 CFR Part 52. This work specifically addresses the following issues: (1) the distribution of iodine species in containment following a loss-of-coolant accident, (2) the generation of hydrochloric acid and nitric acid by irradiation and heating in containment, (3) the formation of elemental iodine in containment water that has both chloride and iodide ions, and (4) the evaluation of $\mathrm{pH}$ levels in containment water.

\section{$2.2 \quad$ PROGRESS}

A new statement of work for this project has been received from the $\mathrm{NRC}$, and a revised proposal has been prepared. This work will include assessments of iodine behavior and $\mathrm{pH}$ control in operating nuclear reactor containments as well as in advanced reactor systems. This task is on hold, awaiting finalization of the revised proposal and receipt of the necessary information from Westinghouse to permit the start of the study. 


\title{
3. THERMODYNAMICS
}

\author{
E. C. Beahm
}

\section{THERMODYNAMICS AND KINETICS OF ENERGY-RELATED MATERIALS (E. C. Beahm and R. D. Hunt)}

Contact: E. C. Beahm

Telephone: (423) 574-6851

Internet: beahmec@ornl.gov

Summary: A differential thermal analysis (DTA)/thermogravimetric analysis (TGA) was used to study the phase transitions of phase-pure $\mathrm{YBa}_{2} \mathrm{Cu}_{3} \mathrm{O}_{6+x}(123)$ at partial oxygen pressures ranging from 1 to $10^{-4.3} \mathrm{~atm}$. Each sample of sintered 123 was allowed to equilibrate for $2 \mathrm{~h}$ at a temperature slightly below the first phase transition. The temperature of the 123 sample was increased at a rate of $1^{\circ} \mathrm{C} / \mathrm{min}$ until a temperature of $1295^{\circ} \mathrm{C}$ was reached. The temperatures of the two phase transitions (based on the DTA results) - (1) $123 \rightarrow \mathrm{Y}_{2} \mathrm{BaCuO}_{5}(211)+$ liquid and (2) $211+$ liquid $\rightarrow$ liquid-were determined. Our current results for the $123 \rightarrow 211$ + liquid transition are in excellent agreement with $\mathrm{K}$. W. Lay's earlier study with a DTA/TGA system. Unfortunately, our results do not agree with those obtained by T. B. Lindemer in an earlier study. Efforts are under way to account for these discrepancies.

\subsection{PURPOSE AND SCOPE}

The objective of this program is the measurement and interpretation of chemical thermodynamics in applied technology ceramic systems. Presently, this project concerns phase equilibria and thermodynamics of the $\mathrm{R}-\mathrm{Ba}-\mathrm{Ca}-\mathrm{Cu}-\mathrm{O}$ system, with $\mathrm{R}$ representing $\mathrm{Y}, \mathrm{La}, \mathrm{Pr}$, and $\mathrm{Nd}$. Emphasis is placed on the phase fields that include the superconducting compounds.

\subsection{PROGRESS}

A sintered sample of phase-pure 123 was used in a series of experiments with a DTA/TGA. The phase transitions of 123 were examined at partial oxygen pressures ranging from 1 to $10^{-4.3} \mathrm{~atm}$. Before each experiment, $0.30 \mathrm{~g}$ of the sintered 123 was ground into a powder. The sample was then transferred into an alumina sample holder and placed into the DTA/TGA. A constant gas flow rate was used regardless of the partial oxygen pressure. The oxygen content was determined with an oxygen analyzer. The temperature of the sample was quickly raised to $860^{\circ} \mathrm{C}$, which is below the first phase transition (based on several different analytical techniques). The sample remained at this temperature for $2 \mathrm{~h}$. At the end of the equilibration, the temperature of the 123 sample was increased at a rate of $1{ }^{\circ} \mathrm{C} / \mathrm{min}$ until a temperature of $1295^{\circ} \mathrm{C}$ was achieved. The temperatures (based on DTA results) of the two phase transitions- $123 \rightarrow \mathrm{Y}_{2} \mathrm{BaCuO}_{5}(211)+$ liquid and $211+$ liquid $\rightarrow$ liquid-are provided in Table 2 . The TGA results indicate slightly higher phase-transition temperature. 
Our current results for the $123 \rightarrow 211+$ liquid transition are in excellent agreement with K. W. Lay's earlier work with a DTA/TGA system. Unfortunately, our results do not agree with those obtained by T. B. Lindemer in an earlier study. Lindemer's paper (Physica C 178, 93-104 [1991])stated that the difference was probably due to the heating rate. However, our current heating procedure should have eliminated this possibility. In addition, Lindemer reported that $211, \mathrm{YBa}_{3} \mathrm{Cu}_{2} \mathrm{O}_{6+x}$ (132), and $\mathrm{BaCuO}_{x}$ were formed from the first phase transition of 123 at an oxygen pressure below $94 \mathrm{~Pa}$ while only 211 and $\mathrm{BaCu}_{2} \mathrm{O}_{2}$ were formed from the same transition at an oxygen pressure above $94 \mathrm{~Pa}$. Samples of the first phase transition of 123 at $1000 \mathrm{~Pa}$ and $10 \mathrm{~Pa}$ of oxygen were prepared for X-ray diffraction analysis. With the exception of the 132 , the same products were observed. Efforts are under way to account for these discrepancies.

Table 2. Temperatures of the two phase transitions

\begin{tabular}{ccc}
\hline $\log \mathrm{pO}_{2}(\mathrm{MPa})$ & $123 \rightarrow 211+\mathrm{L}\left({ }^{\circ} \mathrm{C}\right)$ & $211+\mathrm{L} \rightarrow \mathrm{L}\left({ }^{\circ} \mathrm{C}\right)$ \\
\hline-0.994 & 1038.1 & 1240 \\
-1.994 & 1010.1 & 1200.1 \\
-2.494 & 991.9 & 1185.9 \\
-2.994 & 981.4 & 1160.7 \\
-3.494 & 968 & 1137 \\
-3.994 & 956.3 & 1128.3 \\
-4.494 & 951.4 & 1128 \\
-4.994 & 950.7 & 1114.5 \\
-5.294 & 951 & 1112.4 \\
\hline
\end{tabular}




\title{
4. PROCESSES FOR WASTE MANAGEMENT
}

\subsection{ION-EXCHANGE PROCESS FOR HEAVY METALS REMOVAL (J. C. Rudolph)}

\author{
Contact: J. C. Rudolph \\ Phone: (423) 574-6882 \\ Internet: rudolphjc@ornl.gov
}

Summary: This project provides a transportable pilot-scale ion-exchange system to remove heavy metals from multiple sites using the most effective commercially available sorbent based on laboratory screening experiments. (This work is an extension of the Acid Mine Drainage Treatment Project.) This system will operate alongside three novel treatment systems and serve as baseline technology. The project is being run by the National Institute of Environmental Renewal . Construction of the systems was completed the first week of June, with equipment checkout and programming completed near the end of June. All instrumentation functioned properly, and modem communication with the machine was tested and confirmed. The demonstration trailer was shipped to the Tobyhanna Army Depot on June 26, 1996.

\subsubsection{Purpose and Scope}

The scope of this project has been modified. The original scope was to demonstrate the ability of a pilot-scale ion-exchange system to remove heavy metals from an acid mine drainage site. An initial screening of materials was to be performed to choose the most effective sorbent. This process would then serve as a baseline to compare the abilities of three new innovative technologies to treat the same stream. The project is now investigating heavy metals contamination at multiple sites, none of which are mine drainage sites. This expands the scope since each stream must be treated separately for the purpose of screening tests.

\subsubsection{Progress}

Tobyhanna Army Depot was chosen as the first site to demonstrate the heavy metals removal systems. Project staff were given minimal data on the streams, consisting only of heavy metal content. No data on suspended solids content, $\mathrm{pH}$, other competitive ions, organics, or other complexing agents were supplied. From the available data, it appears that the site does have $\mathrm{Cd}, \mathrm{Cu}, \mathrm{Ni}$, and $\mathrm{Zn}$ in the range of 1 to $3 \mathrm{ppm}$.

The ion-exchange system consists of a filter system to remove suspended solids followed by ionexchange columns to remove the metal ion constituents. The exiting water will be periodically sampled and analyzed for breakthrough. The system is also set up for regeneration and precipitation of the regenerant. The entire system is controlled by a programmable logic controller, which is operated by 
modem. The system is designed to allow up to $2.2 \mathrm{~L} / \mathrm{min}$ of contaminated water to flow. The entire system is located in a trailer.

Construction of the systems was completed the first week of June, and leak checking, instrumentation checkout, and programming were completed near the end of June. All instrumentation functioned properly, and modem communication with the machine was tested and confirmed. The demonstration trailer was shipped to the Tobyhanna Army Depot on June 26, 1996.

Staff from ORNL will be at the site in the beginning of July to initiate the demonstration. As part of the equipment startup, samples of the inlet stream will be obtained for analysis.

\subsection{HOT CELL CROSS-FLOW FILTRATION STUDIES OF GUNITE TANK SLUDGES (A. J. Mattus)}

Contact: A. J. Mattus

Phone: (423) 576-1795

Internet:mattusaj@ornl.gov

Summary: The mobilization of Gunite tank sludges and future MVST sludges requires reliable filtration as a first step in volume reduction. A bench-top, cross-flow filtration apparatus, placed in a hot cell, will filter actual Gunite tank sludges as part of an effort designed to study filtration and operational reliability. The Cell Unit Facility (CUF) unit was received from Savannah River and tested with surrogate sludge outside the hot cell. Following a number of modifications to the unit, it was placed inside the hot cell; a final operational check is in progress. Operational tests with Gunite sludge composites are expected to be completed next quarter.

\subsubsection{Purpose and Scope}

The mobilization of Gunite tank sludges and future MVST sludges requires reliable filtration as a first step in volume reduction. A bench-top, cross-flow filtration apparatus, placed in a hot cell, will filter actual Gunite tank sludges as part of an effort designed to study filtration and operational reliability. With the CUF, sludge is pumped at high tangential velocity over the surface of a sintered metal tube. Solid-free filtrate passes through the tube, while the sludge can be concentrated on the other side. Periodic back-pressure pulses are employed to maintain the filtration rate by unplugging solids in the sintered tube.

\subsubsection{Progress}

The assembled CUF unit was received from Savannah River and tested with surrogate sludge outside the hot cell. A number of modifications were made to the CUF, including a larger reservoir and cooling coils, electric solenoid valves, and a piston-type back-pulse activator. The modified unit will operate with up to $1 \mathrm{~L}$ of sludge feed at a back-pressure of $20 \mathrm{psi}$ and a tangential velocity of $8 \mathrm{ft} / \mathrm{s}$ across 
the sintered tube. The flow rate and temperature are constantly monitored outside the cell electronically, while pressures are read from standard gauges on the unit. The CUF unit was placed inside the hot cell, and a final operational check is in progress. Operational tests with Gunite sludge composites are expected to be completed next quarter.

\subsection{CHEMICAL CONVERSION OF NITRATE DIRECTLY TO NITROGEN GAS: A FEASIBILITY STUDY (A. J. Mattus)}

\section{Contact: A. J. Mattus}

Phone: (423) 576-1795

Internet: mattusaj@ornl.gov

Summary: A bench-top feasibility study to convert nitrate directly to nitrogen gas utilizing aluminum metal with amalgamated surfaces is in preparation. The experimental equipment for processing $200 \mathrm{~mL}$ of $4 \mathrm{M}$ nitrate-based solution has been set up and a safety review completed. Tests of the principle involved are expected to be conducted next quarter.

\subsubsection{Purpose and Scope}

A bench-top feasibility study to convert nitrate directly to nitrogen gas utilizing aluminum metal with amalgamated surfaces is planned as part of an ORNL Seed Money proposal. A chemical process to convert this problematic anion to nitrogen, which could be discharged directly to the atmosphere, would save off-gas processing costs incurred with end products such as ammonia.

\subsubsection{Progress}

The experimental equipment for processing $200 \mathrm{~mL}$ of $4 M$ nitrate-based solution has been set up and a safety review completed. A thermal conductivity detector will measure nitrogen produced in a helium cover gas. Tests of the principle involved are expected to start soon. 


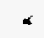

$+$ 
ORNL/M-5462

\section{INTERNAL DISTRIBUTION}

1. J. M. Begovich

2. C. H. Byers

3. E. D. Collins

4. A. G. Croff

5. L. D. Duncan

6-31. B. J. Johnson

32. T. R. Jones

33. R. T. Jubin

34. L. E. McNeese

35. G. E. Michaels

36. B. D. Patton

37. D. E. Reichle

38. S. M. Robinson

39. T. W. Schmidt

40. G. W. Strandberg

41. ORNL Laboratory Records-RC

42. ORNL Patent Office

43. Central Research Library

44. Y-12 Technical Library, Document Reference Center

EXTERNAL DISTRIBUTION

45-46. Office of Scientific and Technical Information, P.O. Box 62, Oak Ridge, TN 37831 